\title{
Role of protein arginine methyltransferase 5 over-expression in HTLV-1-driven cellular transformation and leukemia
}

\author{
Amanda R Panfil ${ }^{1,2^{*}}$, Jacob J Al-Saleem ${ }^{1,2}$, Jesse Kwiek ${ }^{1,3}$, Robert A Baiocchi ${ }^{5}$, Patrick L Green ${ }^{1,2,4,5}$ \\ From 17th International Conference on Human Retroviruses: HTLV and Related Viruses \\ Trois llets, Martinique. 18-21 June 2015
}

Human T-cell leukemia virus-1 (HTLV-1) is a retrovirus that infects an estimated 15-25 million people worldwide. HTLV-1 is the causative infectious agent of adult T-cell leukemia/lymphoma (ATL) and a neurodegenerative disease (HAM/TSP). While the probability of presenting any symptoms related to HTLV-1 infection is relatively low (5-10\% for the lifetime of an infected individual), the disease progression and prognosis of those infected individuals who develop ATL is fatal, with a median survival range of 8-10 months. Unfortunately, ATL is highly chemotherapy resistant and while many current therapies improve ATL patient survival, the patients consistently relapse. Therefore, a need exists to develop treatments that improve ATL outcome. We have recently identified PRMT5 (protein arginine methyltransferase 5) as a potential target to modulate HTLV-1 gene expression. We find that PRMT5 levels are elevated in T-cell leukemia/ lymphoma cell lines compared to freshly isolated naïve T-cells. Likewise, PRMT5 levels are elevated in total PBMCs isolated from ATL patients. However, PRMT5 RNA levels do not correlate to PRMT5 protein levels, suggesting a possible post-transcriptional method of regulation. Furthermore, we also show that PRMT5 levels are elevated during T-cell transformation by using HTLV-1 short-term immortalization assays. Utilizing shRNA vectors, we demonstrate that knockdown of endogenous PRMT5 results in decreased cellular proliferation and increased HTLV-1 viral gene expression. In addition, we observe a decrease in cell proliferation and an increase in viral gene expression when HTLV-1-infected/-transformed cells are treated with a novel small molecule inhibitor of PRMT5 (PRMT5i). Conversely, PRMT5i does not

${ }^{1}$ Center for Retrovirus Research, Comprehensive Cancer Center and Solove Research Institute, USA

Full list of author information is available at the end of the article induce re-activation from HIV-1 chronically infected cells. We previously reported a protein-protein interaction between the HTLV-1 accessory protein, p30, and PRMT5. We further show PRMT5 enhances the ability of p30 to inhibit viral gene expression. In conclusion, we find PRMT5 to be a negative regulator of HTLV-1 and a potential target in HTLV-1-mediated disease.

\section{Authors' details \\ ${ }^{1}$ Center for Retrovirus Research, Comprehensive Cancer Center and Solove Research Institute, USA. ${ }^{2}$ Department of Veterinary Biosciences, Comprehensive Cancer Center and Solove Research Institute, USA. ${ }^{3}$ Department of Microbial Infection and Immunity, Comprehensive Cancer Center and Solove Research Institute, USA. ${ }^{4}$ Department of Molecular Virology, Immunology and Medical Genetics, Comprehensive Cancer Center and Solove Research Institute, USA. ${ }^{5}$ The Ohio State University, Columbus, $\mathrm{OH} 43210$, USA.}

Published: 28 August 2015

doi:10.1186/1742-4690-12-S1-P18

Cite this article as: Panfil et al:: Role of protein arginine

methyltransferase 5 over-expression in HTLV-1-driven cellular

transformation and leukemia. Retrovirology 2015 12(Suppl 1):P18.

Submit your next manuscript to BioMed Central and take full advantage of:

- Convenient online submission

- Thorough peer review

- No space constraints or color figure charges

- Immediate publication on acceptance

- Inclusion in PubMed, CAS, Scopus and Google Scholar

- Research which is freely available for redistribution 